\title{
PEMANFAATAN LIMBAH KAPAS MEDIA JAMUR MERANG SEBAGAI BAHAN DASAR KOMPOS DI DESA BOJONGKULON, KECAMATAN SUSUKAN, KABUPATEN CIREBON
}

\author{
THE UTILIZATION OF STRAW MUSHROOM MEDIA WASTE AS \\ COMPOST MATERIAL IN BOJONGKULON VILLAGE, SUSUKAN SUB- \\ DISTRICT, CIREBON
}

\author{
Siti Wahana ${ }^{1)}$, Ismail Saleh ${ }^{2) *}$, Mutia Intan Savitri Herista ${ }^{3)}$, Dina Dwirayani ${ }^{4)}$ \\ ${ }^{1,3,4}$ Program Studi Agribisnis, Fakultas Pertanian, Universitas Swadaya Gunung Jati, Cirebon \\ ${ }^{2}$ Program Studi Agroteknologi, Fakultas Pertanian, Universitas Swadaya Gunung Jati, Cirebon \\ Email: ismail.saleh68@gmail.com
}

\begin{abstract}
Abstrak : Desa Bojongkulon merupakan salah satu produksi sentra jamur merang di Kabupaten Cirebon dimana limbah jamur merang belum termanfaatkan dengan baik sehingga menjadi masalah bagi masyarakat. Tujuan dari kegiatan pengabdian kepada masyarakat ini untuk memberikan penyuluhan dan pelatihan kepada masyarkat untuk mengelola limbah tersebut menjadi kompos. Metode pengabdian kepada masyarakat ini adalah penyuluhan mengenai potensi limbah jamur, pelatihan pembuatan kompos dan monitoring dan evaluasi. Hasil yang diperoleh dari kegitan ini antara lain masyarakat memiliki kesadaran akan kebersihan lingkungan di wilayah Desa Bojongkulon terutama kelompok tani jamur merang dan masyarakat dapat membuat dan mampu memproduksi kompos berbahan dasar limbah media jamur merang.
\end{abstract}

Kata Kunci: Kompos, limbah, jamur merang, media

Abstract: Bojongkulon village is a central production of straw mushroom in Cirebon. The wastes that produced from mushroom media become a problem because they were not utilized well so they were thrown away to the river. The mushroom media is potentially becomes organic fertilizer. The purpose of this extension activities was to give counselling and training to the people to process those wastes into composts or organic fertilizer. The methods that were used of these activities were giving an explanation to the mushroom farmer that mushroom media wastes can be processed into organic fertilizer, training to mushroom farmer how to process mushroom media, and monitored the progress of the activities. The result of this extension was the mushroom farmer have awareness about environmental cleanliness in Bojongkulon villages. Beside that they can utilise the wastes that produced from mushroom production become organic fertilizer.

Keywords: Compost, media, straw mushroom, waste

\section{PENDAHULUAN}

Desa Bojongkulon adalah salah satu desa yang berada di wilayah Kecamatan susukan Kabupaten Cirebon dengan luas wilayah 198.618 ha dengan jumlah penduduk sebanyak 8.616 jiwa yang terdiri dari 4.043 laki-laki dan 4.573 perempuan dengan jumlah 2.772 kepala keluarga. Letak geografis Desa Bojongkulon adalah berbatasan dengan Desa Kedongdong di sebelah selatan, sebelah utara berbatasan dengan Desa Susukan, sebelah barat berbatasan dengan 
INTEGRITAS : Jurnal Pengabdian

Vol 4, No 2, Desember 2020

ISSN 2580 - 7978 (cetak) ISSN 2615 - 0794 (online)

Desa Kejiwan, sebelah timur berbatasan dengan Desa Tegalgubug. Desa Bojongkulon terdiri dari 6 Dusun/Blok, dengan 6 RW dan 32 RT. Desa Bojongkulon terletak sekitar 26,9 kilometer dari pusat kota Cirebon dan dapat ditempuh selama kurang lebih sekitar satu jam perjalanan.

Desa Bojongkulon merupakan desa pertanian dan perdagangan. Hal ini dapat dilihat dari mayoritas penduduknya sebagai petani dan pedagang. Jenis komoditas utama yang dihasilkan oleh petani di desa ini adalah padi disusul dengan kacang hijau. Jamur merupakan komoditas yang baru diusahakan dalam beberapa tahun terakhir. Pada awal mula usaha tani jamur di Desa Bojongkulon, kumbung jamur yang diusahakan masih sedikit. Semakin lama semakin banyak masyarakat yang tertarik untuk bertani jamur sehingga jumlah kumbung yang ada di Desa Bojongkulon juga semakin meningkat. Sekarang sekitar 100 kumbung jamur yang diusahakan dengan jumlah produksi 12 kuintal per hari, sehingga sekarang Desa Bojong Kulon dikenal juga sebagai desa produsen jamur merang.

Kumbung jamur yang diusahakan oleh kelompok tani kampung jamur pedamaran berada di sekitar aliran sungai. Dengan pertimbangan kondisi cuaca yang sejuk dan lingkungan yang masih alami sehingga cocok untuk tumbuh kembang jamur. Kelompok tani di Desa Bojongkulon menggunakan kapas sebagai bahan utama media tumbuh kembang jamur. Pertimbangan penggunaan kapas (limbah tekstil) sebagai media tanam jamur karena kapas tersebut mudah didapat dan harganya terjangkau. Setiap kumbung jamur menggunakan sekitar satu ton media kapas. Media kapas tersebut akan dicampur dengan dedak, pupuk dan kapur pada saat proses produksi. Lama waktu proses produksi jamur dari awal sampai panen memerlukan waktu sekitar 45 hari. Petani akan membuang media jamur tersebut setelah masa pemanenan selesai.

Petani kampung jamur pedamaran, biasanya membuang limbah media tersebut ke lahan di samping sungai atau langsung ke sungai atau pada lahan di daerah sekitar kumbung jamur. Hal ini tentunya mencemari air sungai dan lingkungan sekitar seperti yang terlihat pada Gambar 1. Sedangkan sebagian masyarakat sekitar masih menggunakan air sungai tersebut untuk mandi dan keperluan rumah tangga lainnya. Kebiasaan masyarakat membuang 
INTEGRITAS : Jurnal Pengabdian

Vol 4, No 2, Desember 2020

ISSN 2580 - 7978 (cetak) ISSN 2615 - 0794 (online)

sampah/limbah di sungai disebabkan karena seringkali sungai dipandang sebagai kawasan yang tidak bernilai ekonomis sehingga tidak perlu ditata dan dijaga kebersihannya serta diposisikan sebagai tempat pembuangan sampah (Indrawati, 2011). Aktivitas warga yang membuang limbah di sungai dapat menurunkan kualitas air sungai seperti meningkatnya nilai BOD, COD, dan nitrat (Yogafanny, 2015; Djoharam et al., 2018). Kuantitas kumbung yang banyak dan masa produksi yang singkat tentunya semakin banyak limbah yang dihasilkan. Hal ini menjadi suatu masalah tersendiri bagi petani jamur dan masyarakat sekitarnya sehingga diperlukan solusi untuk mengatasi masalah limbah media jamur tersebut.

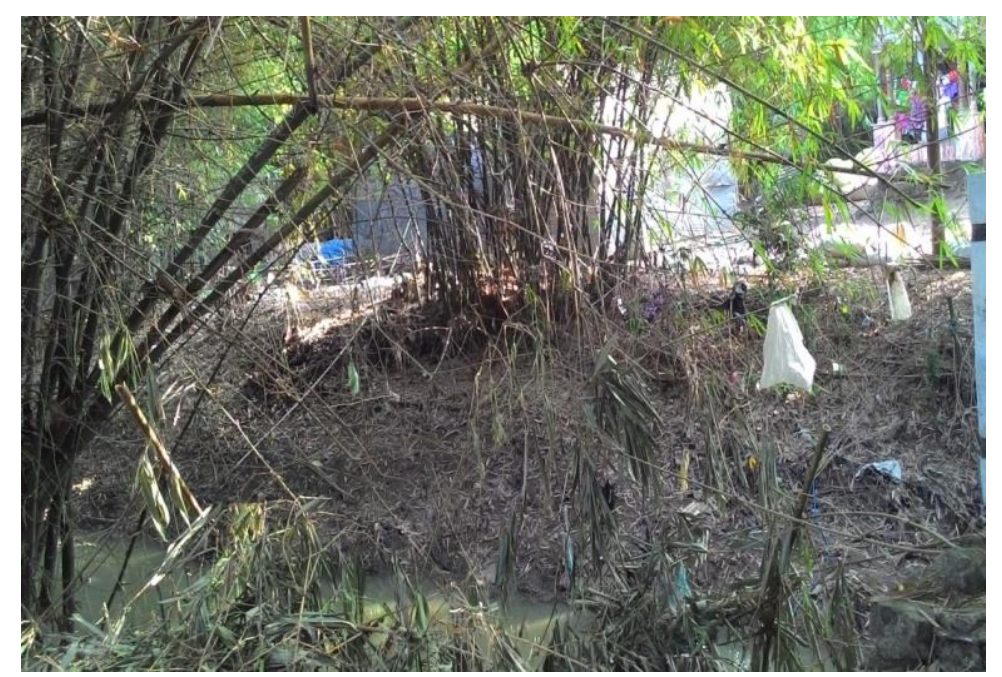

Gambar 1. Kondisi sungai di sekitar kumbung jamur

Berdasarkan permasalah tersebut, tim pelaksana kegiatan pengabdian dari Fakultas Pertanian Universitas Swadaya Gunung Jati mencoba untuk memberikan pelatihan dalam memproses limbah jamur merang tersebut menjadi kompos. Hasil penelitian Purnawanto dan Nugroho (2015) menunjukkan bahwa aplikasi limbah media tanam jamur baik yang dikomposkan maupun tidak dapat meningkatkan pertumbuhan dan hasil tanaman bawang merah. Selain itu Fikri et al. (2015) menyatakan bahwa aplikasi kompos limbah media tanam jamur dapat meningkatkan pertumbuhan dan hasil kangkung darat. Transfer teknologi tersebut diharapkan dapat memberikan manfaat yang besar yaitu adanya peningkatan pengetahuan warga tentang manfaat sampah organik sebagai bahan baku kompos (Suhastyo, 2017). 
INTEGRITAS : Jurnal Pengabdian

Vol 4, No 2, Desember 2020

ISSN 2580 - 7978 (cetak) ISSN 2615 - 0794 (online)

Pengolahan limbah media jamur menjadi kompos telah dilakukan di beberapa daerah seperti di Kelompok Tani Jamur Tiram Mandiri di Tabanan (Widhiantara et al., 2017) dan Kelompok Budidaya Jamur Merang di Desa Panti, Jember, Jawa Timur (Amin dan Prasetyowati, 2018). Dengan permasalahan yang ada dan potensi yang dimiliki maka limbah tersebut dapat dimanfaatkan menjadi kompos diharapkan akan menjadi solusi yang menghasilkan manfaat bagi masyarakat Desa Bojongkulon. Tujuan dari kegiatan pengabdian kepada masyarakat ini untuk memberikan penyuluhan dan pelatihan kepada masyarakat untuk mengelola limbah tersebut menjadi kompos.

\section{METODE}

Kegiatan Pengabdian kepada Masyarakat ini dilaksanakan di Desa Bojongkulon, Kecamatan Susukan, Kabupaten Cirebon. Kegiatan dilaksanakan pada bulan Februari - Maret 2018. Sasaran kegiatan ini adalah Kelompok Tani Kampung Jamur Padamaran.

Melihat potensi dari limbah media jamur yang tidak termanfaatkan tersebut maka solusi yang ditawarkan adalah memanfaatkan limbah media jamur merang tersebut menjadi kompos yang dapat digunakan sebagai pupuk organik. Tahapantahapan yang dilakukan dalam kegiatan pengabdian masyarakat ini antara lain sebagai berikut:

1. Tahap persiapan. Tahap ini meliputi survey dan analisis pendahuluan mengenai potensi yang terdapat pada Kelompok Tani Kampung Padamaran.

2. Penyuluhan kepada anggota Kelompok Tani Kampung Padamaran. Penyuluhan ini bertujuan untuk meningkatkan pengetahuan tentang pentingnya kebersihan lingkungan serta meningkatkan pengetahuan kelompok jamur padamaran tentang pembuatan kompos dengan transfer teknologi tentang pengelolaan limbah media jamur merang.

3. Pelatihan pembuatan kompos media jamur merang dengan memanfaatkan tambahan bahan-bahan yang tersedia.

4. Pelatihan penanaman sayuran dengan menggunakan media kompos limbah jamur merang. 
INTEGRITAS : Jurnal Pengabdian

Vol 4, No 2, Desember 2020

ISSN 2580 - 7978 (cetak) ISSN 2615 - 0794 (online)

Jenis Luaran yang dihasilkan dari kegiatan pengabdian kepada masyarakat ini adalah:

1. Masyarakat Desa Bojongkulon terutama masyarakat yang memproduksi jamur mampu mengelola dan menjaga kebersihan lingkungan dengan baik.

2. Masyarakat Desa Bojongkulon dapat memanfaatkan kompos limbah kapas media jamur yang dihasilkan sehingga tidak mencemari lingkungan.

\section{HASIL DAN PEMBAHASAN}

Pelaksanaan kegiatan Pengabdian Kepada Masyarakat ini dibagi menjadi beberapa tahapan yaitu:

1. Tahap Persiapan

Pada tahap ini dilaksanakan sebagai langkah awal dalam melaksanakan program pengabdian ini. Sosialisasi dilakukan dengan mengadakan pertemuan awal kepada aparatur desa setempat, kader masyarakat serta ketua kelompok tani (Gambar 2). Hal ini bertujuan untuk kelancaran kegiatan.

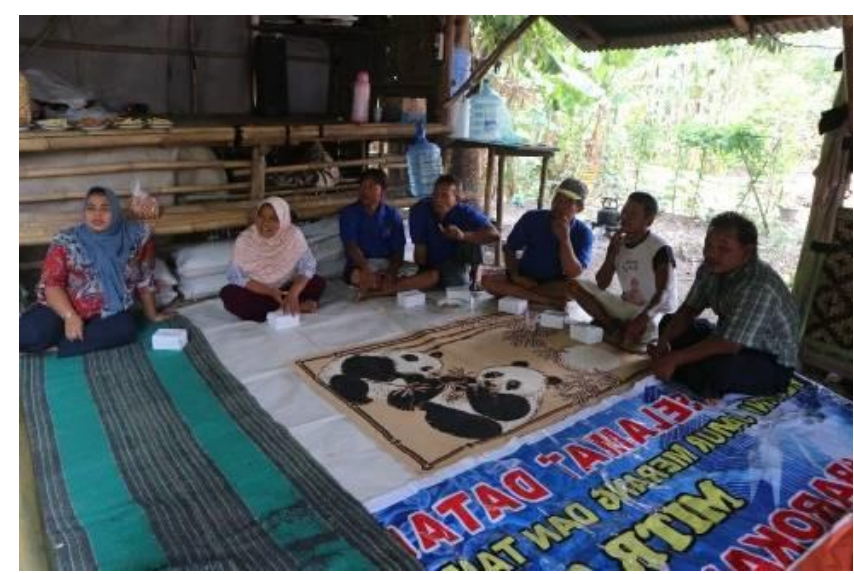

Gambar 2. Pertemuan dengan aparat desa dan perwakilan kelompok tani

2. Tahap Pelaksanaan

Tahap pelaksanaan meliputi beberapa kegiatan diantaranya:

a. Penyuluhan. Penyuluhan dilaksanakan di daerah sekitar kumbung jamur miliki Kelompok Tani di Desa Bojongkulon. Kegiatan penyuluhan ini melibatkan aparat desa, pemilik kumbung jamur, serta masyarakat umum (Gambar 3). Tujuan dilaksanakannya penyuluhan ini supaya masyarakat lebih peduli terhadap kebersihan lingkungan serta dapat mengenal potensi 


\section{INTEGRITAS : Jurnal Pengabdian}

Vol 4, No 2, Desember 2020

ISSN 2580 - 7978 (cetak) ISSN 2615 - 0794 (online)

dari limbah media jamur. Hal ini mengingat limbah media jamur tersebut belum termanfaatkan dengan baik bahkan mencemari lingkungan karena dibuang di daerah aliran sungai.

Selain itu, saat penyuluhan juga disampaikan tentang manfaat dari kompos, tata cara pembuatan kompos sampai potensi secara ekonomi dari kompos yang sudah dibuat sehingga berpotensi untuk memberikan nilai tambah pada usaha tani jamur merang seperti yang telah dilakukan oleh Kelompok Budidaya Jamur Tiram Lombok di Desa Barejulat (Hunaepi et al., 2018). Penyuluhan dapat dianggap efektif untuk menyampaikan materi karena dapat meningkatkan pemahaman masyarakat tentang nilai ekonomis sampah dan meningkatkan keterampilan dalam pembuatan kompos (Astuti dan Haryono, 2018).
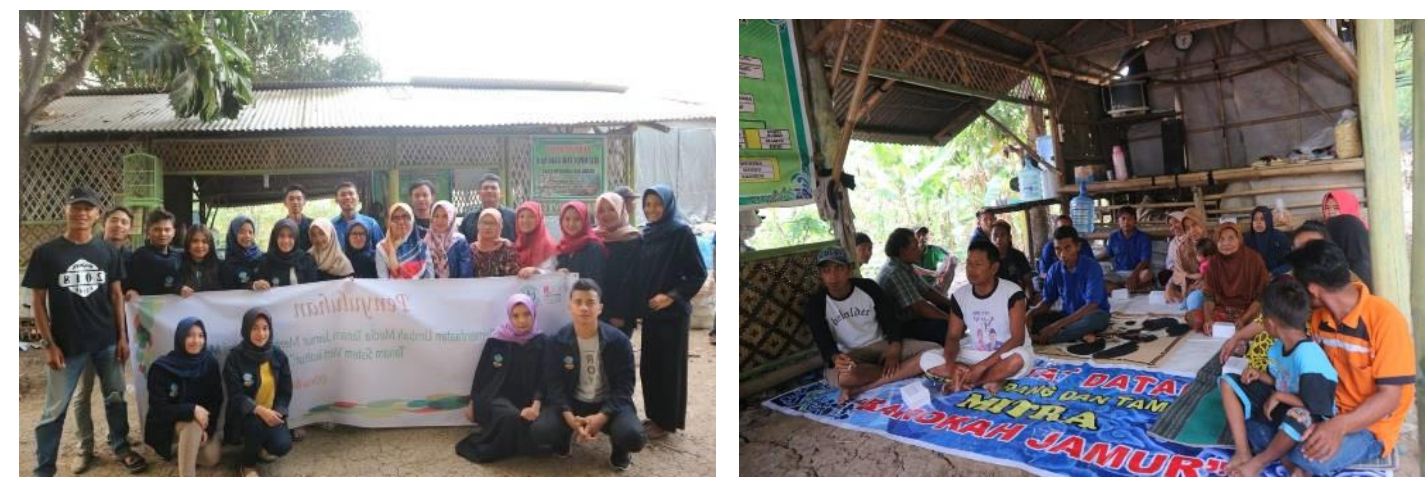

Gambar 3. Penyuluhan kepada kelompok tani jamur dan masyarakat sekitar

b. Pelatihan. Kegiatan pelatihan dibagi menjadi beberapa tahap yaitu penentuan lokasi pembuatan kompos, persiapan alat dan bahan, pembuatan kompos, perawatan, pemanenan kompos, serta pemanfaatan dari kompos yang sudah jadi. Pembuatan kompos dilakukan di dekat kumbung jamur (Gambar 4). Hal tersebut memudahkan dalam pengangkutan limbah media dari kumbung jamur ke tempat pembuatan kompos. Persiapan alat-alat yang dibutuhkan untuk pembuatan kompos dilakukan oleh warga antara lain tong tempat air, ember, cangkul, limbah media jamur serta bahanbahan tambahan lainnya yang meliputi pupuk kandang, EM4 dan daun bambu. 
Pelatihan pembuatan kompos dari limbah media jamur merang berlangsung sangat efektif dengan antusiasme warga yang sangat tinggi untuk dapat membuat kompos sendiri dari bahan yang sudah tersedia di sekitar tempat tinggal mereka. Widhiantara et al. (2017) menyatakan bahwa masyarakat selama ini tidak memanfaatkan media jamur tiram tersebut karena kurang informasi mengenai pemanfaatan limbah media jamur tersebut. Perawatan kompos selama proses pengomposan dilakukan sendiri oleh warga setelah mendapat pengarahan dari tim pelaksana kegiatan.

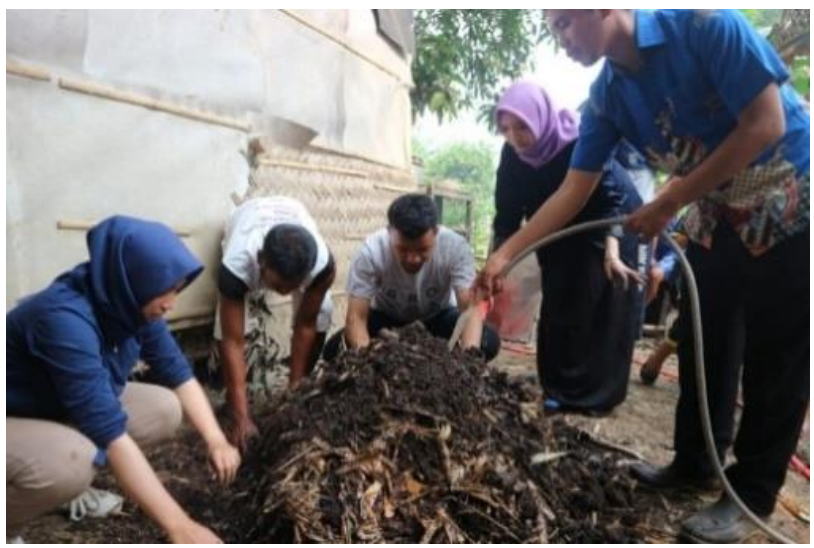

Gambar 4. Proses pembuatan kompos dari limbah media jamur merang

Produk akhir yang diharapkan dari proses pembuatan kompos dari limbah media jamur merang ini adalah pemanfaatan kompos tersebut sebagai pupuk organik atau sebagai media tanam tanaman sayuran yang dapat ditanam di pekarangan. Oleh karena itu saat pelatihan juga disampaikan materi untuk menyemai beberapa jenis sayuran seperti kangkung, selada, dan pakchoy (Gambar 5). Sayuran tersebut diharapkan dapat dibudidayakan dengan menggunakan kompos dari limbah media jamur yang telah dibuat sebelumnya. Suhastyo (2017) menyatakan bahwa penggunaan pupuk organik dapat mendukung untuk mewujudkan ketahanan pangan melalui pemanfaatan pekarangan untuk menanam berbagai jenis sayuran. 


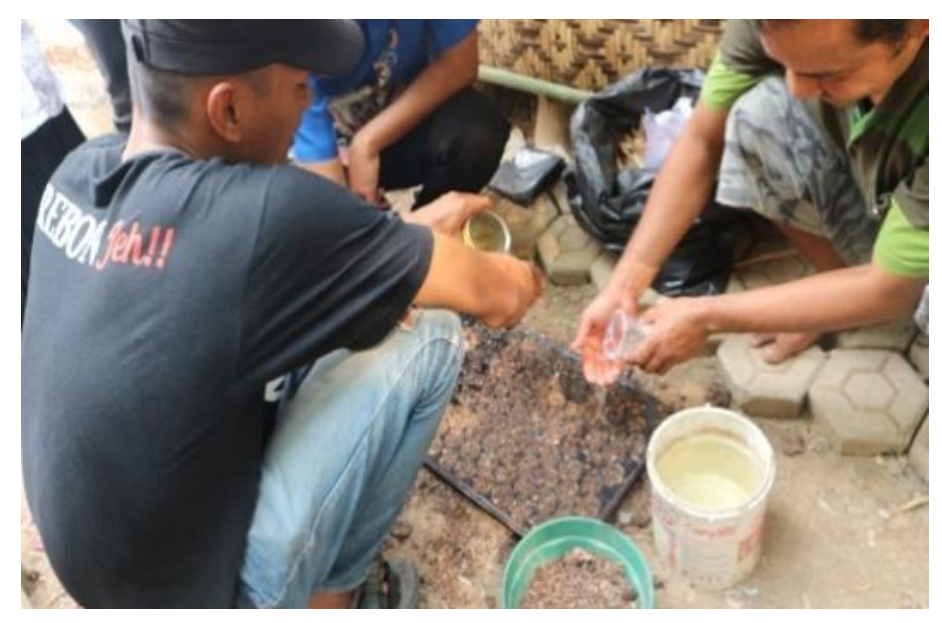

Gambar 5. Penyemaian beberapa jenis sayuran

3. Evaluasi

Evaluasi dilakukan dengan memantau keberlanjutan program pembuatan kompos dari limbah media jamur merang. Berdasarkan hasil evaluasi, warga sangat antusias untuk melakukan perawatan terhadap kompos limbah media jamur merang serta secara sukarela menggunakan kompos tersebut sebagai media tanam atau pupuk organik dari tanaman mereka. Masyarakat mengakui keunggulan dari kompos limbah media jamur merang tersebut. Mereka telah membuktikan bahwa limbah media jamur merang sangat cocok apabila digunakan sebagai pupuk organik.

\section{KESIMPULAN}

Berdasarkan hasil kegiatan pengabdian masyarakat yang telah dilakukan di Kelompok Tani Jamur Padamaran, Desa Bojong Kulon, target luaran tercapai yaitu masyarakat mengetahui tentang manfaat dan potensi dari limbah media jamur yang sebelumnya terbuang dan bahkan mencemari aliran air sungai, dapat dimanfaatkan sebagai bahan baku kompos. Tingkat partisipasi masyarakat yang cukup tinggi dan antusiasme masyarakat dalam mengikuti program penyuluhan dan pelatihan sangat membantu dalam menyukseskan program pengabdian masyarakat tersebut. 
INTEGRITAS : Jurnal Pengabdian

Vol 4, No 2, Desember 2020

ISSN $2580-7978$ (cetak) ISSN 2615 - 0794 (online)

\section{UCAPAN TERIMA KASIH}

Ucapan terima kasih disampaikan kepada Lembaga Pengabdian kepada Masyarakat Universitas Swadaya Gunung Jati yang telah membiayai program kegiatan masyarakat ini melalui hibah pengabdian kepada masyarakat tahun 2018.

\section{DAFTAR PUSTAKA}

Amin, S. dan Prasetyowati, A. H. (2018). Peningkatan Produktivitas Budidaya Jamur Merang di Desa Panti Kabupaten Jember. Jurnal Pengabdian Masyarakat Ipteks, 4(2), 91-101.

Astuti, A. dan Hariyono.(2018). Pelatihan dan Pendampingan Kelompok Wanita Tani untuk Pembuatan Kompos dengan Bioaktivator Mold an Dikelola Melalui Bank Kompos. Jurnal Bakti Saintek, 2(1), 37-42.

Djoharam, V., Riani, E., dan Yani, M. (2018). Analisis Kualitas Air dan Daya Tampung Beban Pencemaran Sungai Pesanggrahan di Wilayah Provinsi DKI Jakarta. Jurnal Pengelolaan Sumberdaya Alam dan Lingkungan, 8(1), 127-133.

Fikri, M.S., Indradewa, D., Putra, E. T. S. (2015). Pengaruh Pemberian Kompos Limbah Media Tanam Jamur pada Pertumbuhan dan Hasil Kangkung Darat. Vegetalika, 4(2), 79-89.

Hunaepi, Dharmawibawa, I. D., Samsuri, T., Mirawati, B., dan Asy'ari, M. (2018). Pengolahan Limbah Baglog Jamur Tiram Menjadi Pupuk Organik Komersil. Jurnal SOLMA, 7(2), 277-288.

Indrawati, D. (2011). Upaya Pengendalian Pencemaran Sungai yang Diakibatkan Oleh Sampah. TJL, 5(6), 193-200.

Purnawanto, A. M. dan Nugroho, B. (2015). Efektivitas Kompos Limbah Media Tanam Jamur Tiram Sebagai Pupuk Organik pada Budidaya Bawang Merah di Tanah Ultisol. Agritech, 17(2), 97-105.

Suhastyo, A. A. (2017). Pemberdayaan Masyarakat Melalui Pelatihan Pembuatan Pupuk Kompos. Jurnal Pengabdian dan Pemberdayaan Masyarakat, 1(2), 63-68.

Widhiantara, I. G., Rosiana, I. W., dan Permatasari, A. A. A. P. (2017). Pemanfaatan Limbah Baglog Jamur Tiram Sebagai Media Tanam Organik pada Budidaya Bunga Gemitir (Tagetes erecta). Jurnal Paradharma, 1(1), 23-27.

Yogafanny, E. (2015). Pengaruh Aktivitas Warga di Sempadan Sungai terhadap Kualitas Air Sungai Winongo. Jurnal Sains dan Teknologi Lingkungan, 7(1), 41-50. 